
\title{
3 Research Square \\ Do Defensive Compounds Affect the Success of Invasion of the Argentine Ant?
}

Isabel Salado ( $\boldsymbol{\nabla}$ isalado@ebd.csic.es )

Estación Biológica de Doñana: Estacion Biologica de Donana CSIC https://orcid.org/0000-0002-88612436

PALOMA ALVAREZ-BLANCO

Estación Biológica de Doñana: Estacion Biologica de Donana CSIC

RAPHAËL BOULAY

Institut de recherche sur la biologie de l'insecte

OLIVIER BLIGHT

Avignon Université: Avignon Universite

SÍLVIA ABRIL

Universitat de Girona

XIM CERDÁ

Estación Biológica de Doñana: Estacion Biologica de Donana CSIC

ELENA ANGULO

Estación Biológica de Doñana: Estacion Biologica de Donana CSIC

\section{Research Article}

Keywords: Allomone, biological invasions, chemical defense, invasive ants, Linepithema humile, unicoloniality

Posted Date: August 9th, 2021

DOI: https://doi.org/10.21203/rs.3.rs-708420/v1

License: (c) (i) This work is licensed under a Creative Commons Attribution 4.0 International License.

Read Full License 


\section{Abstract}

One of the main traits of invasive ants is the formation of supercolonies, large networks of polygynous nests lacking intraspecific competition, which allows them to reach high densities that facilitate their spread. However, different supercolonies exhibit different success in expanding along the world. Here, we explore whether the main chemical defensive compound of the Argentine ant could play a role in the differential invasiveness of supercolonies. We assessed differences in the amount of iridomyrmecin among supercolonies in the native range and in three invasive supercolonies: the Main supercolony (the most extended worldwide), and the Corsican and the Catalonian supercolonies (both with a restricted local distribution in Europe). We found that even if the amount of iridomyrmecin varied greatly between invaded regions in the three supercolonies in Europe and the native supercolonies in South America, the differences did not seem related to the success of invasion. The amount of iridomyrmecin of the Main supercolony was the lowest while the highest corresponded to the Corsican supercolony, with the Catalonian having intermediate values. This suggests that the success of a given invasive supercolony may not be explained by higher quantities of this defensive compound. Alternatively, reducing iridomyrmecin quantities in the invasive range could lead to more investment in other fitness traits that increase the invader's competitive ability. Our results open the way for exploring the contribution of defensive compounds in the competitive ability and spread of this global invader.

\section{Introduction}

In the last decades, biological invasions have become one of the main threats to biodiversity and ecosystem services in the whole world (Millennium Ecosystem Assessment 2005), leading to a global redistribution of species and driving homogenization of ecosystems in our planet (McKinney and Lockwood 1999, 2001). The Argentine ant (Linepithema humile, Mayr 1868) is one of the most devastating invasive species in the world (Holway et al. 2002). Native to South America, it has spread worldwide, mainly in regions with Mediterranean climate (Suarez et al. 2001; Wetterer et al. 2009; Vogel et al. 2010). The Argentine ant has a strong economic impact (Angulo et al. 2021) and also a heavy ecological impact on the invaded ecosystems, because it does not only displace the local arthropod fauna (Bolger et al. 2000; Holway and Suarez 2004), but it also causes a series of cascade effects in the rest of ecosystem, from plants (Christian 2001; Blancafort and Gómez 2005) to vertebrates (Suarez et al. 2000; Alvarez-Blanco et al. 2020, 2021). For these reasons, it has been registered on the ' 100 of the World's Worst Invasive Alien Species' list (Lowe et al. 2000; GISD 2021).

Similar to many ant invaders, the success of the Argentine ant has been shown to rely on its social organization, known as unicoloniality, based on the formation of supercolonies. Supercolony consists of large networks of polygynous nests (multiple queens) genetically homogeneous that exhibit no aggression with each other, even if they are separated by long distances. However, strong aggression among supercolonies is always present (Helanterä et al. 2009; Vogel et al. 2009). In their native range, Argentine ants' supercolonies are small and spatially restricted to just hundreds of meters (Pedersen et al. 2006; Suarez and Tsutsui 2008; Vogel et al. 2009; Josens et al. 2017). This is because they have to deal 
with interspecific competition - with the rest of the ant community - and intraspecific competition among nearby supercolonies (Vogel et al. 2009). However, in its introduced range, supercolonies are much larger and allow the Argentine ant to reach high densities and spread thoroughly (Vogel et al. 2009, 2010). To date, it has been found a total of 14 distinct introduced supercolonies with a highly variable distribution (Vogel et al. 2010). In Europe, Giraud et al. (2002) found two distinct introduced supercolonies: the Main supercolony, which ranges over $6,000 \mathrm{~km}$ from Italy to the Spanish Atlantic coast including Canary and Balearic Islands, and the Catalonian supercolony, which is restricted to the Spanish East coast and Balearic Islands. Blight et al. (2010) discovered a third European supercolony, the Corsican supercolony, which is localized in the South of France and the Corsica Island. All three supercolonies are expanding, but the Main supercolony seems to show the highest expansion along the coast of Mediterranean islands (Castro-Cobo et al. 2021).

Across the globe, the Main supercolony is one of the most successful invasive populations of the Argentine ant; it has been established in every continent the Argentine ant has invaded, including several countries like USA, France, Spain, Japan, Australia, New Zealand, and South Africa (Vogel et al. 2010). It has been recently shown how secondary introductions could be important for the spread of invasive species, where the number of primary introduced locations fosters new invasion events (Bertelsmeier and Keller 2018). This could alone explain why the Main supercolony displays a higher distribution range (Castro-Cobo et al. 2021). However, the Main supercolony also displays a high level of aggressiveness and a characteristic exploratory behaviour, which have been shown to be the cause for its ecological dominance over secondary supercolonies and the native ant communities and, consequently, for its invasion success (Thomas et al. 2005; Sunamura et al. 2009; Abril and Gómez 2011; Blight et al. 2017). Although it is still not clear why while the Main supercolony spans for thousands of kilometres in Southern Europe, the Catalonian and the Corsican supercolony are restricted to small areas (Giraud et al. 2002; Blight et al. 2012).

Several studies have shown genetic differentiations between native and introduced populations that possibly affect recognition cues, i.e., cuticular hydrocarbons, those mediate in the nestmate distinction and determine the aggressive behaviour among them (Suarez et al. 1999; Tsutsui et al. 2000; Tsutsui and Case 2001; Giraud et al. 2002; Brandt et al. 2009). Most studies have focused on genetic, chemical and behavioural recognition approaches, but little is known about the role of chemical compounds, such as pheromones and allomones, in the supercolonies' success. These compounds play an important role in communication in social insects (D'Ettorre and Lenoir 2010). Different functions have been described e.g. trail following and home range, sexual attraction, aggregation and dispersal, and alarm and defense (Billen and Morgan 1998). Iridomyrmecin is a member of cyclopentanoid monoterpenes, also known as iridoids (Cavill 1969). It is produced in the pygidial gland localized in the gaster of some Dolichoderinae ant, mainly responsible for defensive secretion (Billen 1986). Iridomyrmecin is the major component of the pygidial gland in the Argentine ant, reaching approximately $2 \%$ of its body weight (Cavill and Houghton 1974; Alvarez-Blanco et al. 2021). This compound was firstly isolated by Pavan 1949), who reported its bactericidal and insecticidal properties (Pavan 1952a, b). While iridomyrmecin has been linked to roles such as chemical signal in necrophoresis (Choe et al. 2009) or trail pheromone - acting 
together with dolichodial and (Z)-9-hexadecenal (Choe et al. 2012) -, Welzel et al. (2018) revealed that iridomyrmecin (and dolichodial) function as defensive allomones, causing high levels of irritation in the heterospecific competitors of the Argentine ant, such as the California harvester ant (Pogonomyrmex californicus). Moreover, iridomyrmecin has been identified to be the venom compound used by the Argentine ant to predate over young amphibians (Alvarez-Blanco et al. 2021).

In fact, three of the five ant species appearing in the list of 100 of the world's worst invasive organisms are considered venomous, poisoning or toxic: the red imported fire ant, Solenopsis invicta, the little fire ant, Wasmannia auropunctata and the yellow crazy ant, Anoplolepis gracilipes (Lowe et al. 2000; GISD 2021). However, the venom of the Argentine ant has received some attention recently (Welzel et al. 2018; Alvarez-Blanco et al. 2021), probably because $L$. humile is not considered as a venomous ant species sensu stricto for several reasons. First, the Argentine ant, like other Dolichoderinae, lacks a functional sting associated with poison gland (Billen 1986), most defensive secretions come from the extremely large pygidial gland instead (Billen 1986) and are usually applied directly on enemies' surfaces (Leclercq et al. 2000; Welzel et al. 2018). Second, the high volatility of iridoids makes them difficult to isolate and may suggest a reduced toxicity. Indeed, insecticidal effects of iridoids appear to be only temporary (Welzel et al. 2018), and some studies have claimed that iridoids show low toxicity (Cavill and Clark 1971; Attygalle and Morgan 1984). Third, the chemical composition of iridomyrmecin differs from the rest of invasive ants' venoms. Whereas $L$. humile produces iridomyrmecin, a non-glycosidic iridoid (Franzyk 2000), stinging Myrmicinae ants (e.g. S. invicta and W. auropunctata) produce alkaloids, widely researched because of their numerous anthropogenic and animall applications (Aniszewski 2015). As a result, iridomyrmecin, and iridoids in general, have received little attention in comparison with alkaloids.

Here we propose that iridomyrmecin, acting as a chemical compound used in aggressive confrontations, could be contributing to the differences in the invasion success of the supercolonies of the Argentine ant. Invasive species show different strategies to spread and establish self-sustaining populations in new ranges (Catford et al. 2009; Ricciardi et al. 2013). On the one hand, in the invaded range, the Argentine ant could have invested in a greater quantity of iridomyrmecin to face potential competitors or predators in the recipient community. This hypothesis would be consistent with Welzel et al. (2018), who elucidated that invasive Argentine ants' iridomyrmecin plays a key role for defense against heterospecific competitors. Thus, iridomyrmecin would act as a defensive weapon that would enhance its competitive ability and success. In this case, we would expect that Argentine ants from invaded areas show a greater quantity of iridomyrmecin than those from native areas. In the same manner, the more successful introduced supercolonies (i.e., Main colony) would possess higher quantities of iridomyrmecin than those with limited distribution. Alternatively, according to the Enemy release hypothesis and the Evolution of increased competitive ability hypothesis (Elton 1958; Blossey and Notzold 1995; Sih et al. 2010), in the absence of their natural competitors, invasive Argentine ants could have allocated freed resources (i.e., those used to produce iridomyrmecin to defend from competitors and predators that limited their native distribution) to adapt and enhance its competitive ability. Thus, these freed resources could be allocated on other life history traits related to invasiveness. In this case, we would expect higher quantities of 
iridomyrmecin in Argentine ants from the native range compared to introduced ants and in less successful supercolonies (i.e., Catalonian and Corsican colonies) compared to the Main supercolony.

In this study, we compare differences in iridomyrmecin quantities among different locations where the Argentine ant is present (including both, native and invasive ranges) and among invasive supercolonies (Main, Catalonian and Corsican) in order to respond to the following questions: Are the most successful supercolonies those with a greater chemical arsenal, i.e. greater amount of iridomyrmecin? Are iridomyrmecin quantities higher in the invasive range than in the native range? In order to respond to these questions, we assessed differences in the quantities of iridomyrmecin at different levels: (i) differences among supercolonies in the native range, Buenos Aires, Argentina; (ii) differences within each invaded supercolony (Main, Corsican and Catalonian) at different regions in Europe and (iii) differences among supercolonies, including the native supercolonies and the three invasive supercolonies. To discard the effect of any potential loss of the volatile compound through manipulation, we also verified whether iridomyrmecin quantities are maintained in workers following disturbance.

\section{Methods And Materials}

Disturbance Experiment. In order to test whether disturbance of workers due to sampling produced a loss of iridomyrmecin, we performed an experiment to see the likely loss and recovery in the quantities of iridomyrmecin before and after disturbance. Ants were sampled in an invaded area at Doñana Biological Reserve ( $37^{\circ} 1^{\prime}$ N, $6^{\circ} 33^{\prime}$ W; Doñana National Park, Spain) in July 2015. First, we collected ten workers directly from an ant trail and considered them as basal iridomyrmecin (control). Each ant was collected independently and immediately preserved in a vial with $2 \mathrm{~mL}$ of hexane. To minimize disturbance, we collected them with extreme caution, approximating soft tweezers to an ant and let it climb into the tweezers without disturbing the ant trail. Then, we collected around 300 ants into an artificial colony plastic box and brought them to the lab. Then, we disturbed the ants by shaking the nest and sampled ten workers at each of these times: 0 min, $1 \mathrm{~h}, 12 \mathrm{~h}, 24 \mathrm{~h}, 2$ days, 4 days, 7 days and 14 days. The colony fragment was maintained in laboratory conditions and the ants were fed with mealworm larvae, small crickets and diluted honey. We wore gloves when manipulating the samples and cleaned the tweezers with cotton soaked in alcohol after the collection of each worker.

Sampling among and within Supercolonies. Argentine ants were obtained from their original range at Buenos Aires (Argentina) and from invaded areas in the Iberian Peninsula, Canary and Balearic Islands (Spain) and southern France, which included the Main, the Catalonian and the Corsican supercolonies (Fig. 1a; Table S1). In the native range, at Buenos Aires, ants from five colonies were sampled, which are known to be highly aggressive among them. For the Main and Catalonian supercolonies, we sampled nine and three regions respectively. Regions were at least $50 \mathrm{~km}$ apart or in different islands, along the Mediterranean and Atlantic coast of the Iberian Peninsula and in the Balearic and Canary Islands. Within each region, we collected more than one nest when possible, which were at least $500 \mathrm{~m}$ apart from each other. For the Corsican supercolony, we sampled three nests in southern France. 
The sampling was done with the same procedure described above for the control treatment in the disturbance experiment: one ant each time without disturbing the ants of the track and immediately preserved in $2 \mathrm{~mL}$-vial of hexane. We collected between 10 to 15 ants per nest.

Assignment to the Main, the Catalonian or the Corsican supercolony was based on the results of one-toone interactions, following a protocol designed by X. Espadaler (Castro-Cobo et al. 2021). We performed encounters in Petri dishes confronting two individual workers, one of a known supercolony (Main, Catalonian or Corsican) and the other of the unknown supercolony; five repetitions are enough to show whether the unknown supercolony pertains or not to the known supercolony if the encounters are pacific or aggressive, respectively.

Chemical Analyses. Iridomyrmecin levels were analysed using gas chromatography (GC/FID - Shimadzu 2010 equipped with a $30 \mathrm{~m} \times 0.25 \mathrm{~mm}$ i.d.-BPX5, $0.25 \mathrm{~mm}$ capillary column). Helium was used as the carrier gas (flow rate of $35.1 \mathrm{ml} / \mathrm{min}$ ). The injection port and detector temperatures were set to $280^{\circ} \mathrm{C}$ and $310^{\circ} \mathrm{C}$, respectively. The $\mathrm{GC}$ oven was programmed to heat at a rate of $10^{\circ} \mathrm{C} / \mathrm{min}$ from $60^{\circ} \mathrm{C}$ to $300^{\circ} \mathrm{C}$, with a 1-min initial hold and a 20-min final hold. Decyl-alcohol (99\%) was used as the internal standard, and the calibration curve for quantifying iridomyrmecin concentrations in the samples was constructed using synthetic iridomyrmecin. Compound quantifications were then determined by calculating the area under the peak relative to the internal standard for the different samples and corrected by the calibration curve. Manual peak integration and the calibration curve were performed using GC-solution software v.2.3 (Shimadzu, 2010).

After chemical analysis, an estimation of the size of each ant was obtained. The inter-ocular distance was measured under a stereomicroscope (Zeiss Stereo Discovery v.8).

Statistical Analyses. In the disturbance experiment, iridomyrmecin quantities (dependent variable) were analysed using linear models employing a Gaussian distribution, using stats and car (Fox and Weisberg 2011) packages in $R$ software ( $R$ Core Team 2016). Time after disturbance was the fixed independent variable and ant size was included as a covariable. To evaluate the treatment effect, we computed an ANOVA (using the "anova" function from the car package) and performed paired planned comparisons between the control level and the rest of treatment levels ( 0 min, $1 \mathrm{~h}, 12 \mathrm{~h}, 24 \mathrm{~h}, 2$ days, 4 days, 7 days and 14 days) (using the " $/ m$ " function from stats package). Both, residual normality and variance homogeneity, were checked with Shapiro-Wilk test and Breusch-Pagan test, respectively.

The following models were performed for testing differences in the amount of iridomyrmecin among: (i) Native supercolonies collected in the native range; (ii) Main supercolony regions; (iii) Catalonian supercolony regions; (iv) Corsican supercolony nests and (v) Supercolonies, including the native (Buenos Aires supercolonies) and the invasive range (Main, Catalonian and Corsican supercolonies). We performed a linear model for the differences among native supercolonies (square root transformation of variable response to fulfill normality assumptions) and Corsican nests. We used general linear mixedeffects models with gamma distribution and log-link function for the differences among regions of the Main and the Catalonian supercolonies, and to see differences among invaded and native supercolonies. 
In all mixed-models covariance of ants pertaining to the same nests was taken into account by including the nest as a random factor. Also, all models included as covariate the distance between the ant eyes to account for the ant size. An optimizer was included in the Main and Catalonian supercolonies models to solve convergence problems. Linear models were fitted using the " $/ m^{\prime \prime}$ function in the R package stats (R Core Team 2016) and general mixed models were fitted using " $g / m e r$ " function in the R package Ime4 (Bates et al. 2015). In order to test the effect of each independent variable, we used an anova for linear models ( $F$ statistic) and "drop1" function for mixed models, both from the stats package (R Core Team 2016). The "drop 1" function compares the model including and excluding the variables based on the likelihood-ratio test statistics $(L R T$, option test $=$ "Chl"). Finally, when significant differences were found, we performed pairwise post-hoc comparison, using the Ismeans package (Lenth 2016). In the analysis comparing the invaded and native supercolonies, beside pairwise comparisons among Main, Catalonian, Corsican and native supercolonies, an a priori contrast was defined in order to compare the three invasive supercolonies to the native supercolonies using the " $g / h t$ " function in the multcomp package (Hothorn et al. 2008). Analyses were performed under R version 4.0.0.

Repeatability was tested for GC-Shimadzu, manual peak integration and ant size measurements following (Senar 1999) (Table S2).

\section{Results}

Disturbance Experiment. Iridomyrmecin quantities were positively correlated to ant size $(F=8.57, p=$ $0.004, N=88)$, but they were not affected by disturbance $(F=1.03, p=0.424, N=88)$. No significant differences were found among the control (undisturbed) and the rest of the treatments (different times after disturbance; $p>0.1$ in all cases; Fig. 2; Table S3). Therefore, disturbance of workers did not produce significant changes in iridomyrmecin quantities and there is no pattern of loss or recovery in iridomyrmecin after disturbance.

Differences in Iridomyrmecin among Supercolonies in the native range. Iridomyrmecin quantities did differ among the five supercolonies in the native range of $L$. humile collected in Buenos Aires $(F=3.13, \mathrm{p}$ $=0.020, N=73$ ). However, post-hoc comparisons did not show differences among supercolonies (Fig. $1 \mathrm{~b}$; Table S4a). Ant size was not correlated with iridomyrmecin quantities $(F=0.11, \mathrm{p}=0.740, \mathrm{~N}=73)$.

Differences in Iridomyrmecin within Supercolonies. In the Main supercolony, iridomyrmecin quantities were different depending on the region $(L R T=28.79, \mathrm{p}<0.001, \mathrm{~N}=421)$. Iridomyrmecin quantities were positively correlated to ant size $(L R T=17.92, \mathrm{p}<0.001, \mathrm{~N}=421)$. Post-hoc comparisons showed significant differences among some of the regions within the wide range occupied by the Main supercolony although differences did not seem to be related with geographic proximity (Table S4b; Fig. $1 \mathrm{~b}$ ). In the Catalonian supercolony, iridomyrmecin quantities differed among regions $(L R T=10.06, \mathrm{p}$ $=0.007, \mathrm{~N}=108)$ and were positively correlated to ant size $(L R T=5.94, \mathrm{p}=0.015, \mathrm{~N}=108)$. Region located on the Pitiusas islands, was the one showing significant difference with the other two continental regions (Table S4c; Fig. 1b). In the Corsican supercolony, iridomyrmecin quantities differed among regions ( $F=$ 
3.28, $\mathrm{p}=0.045, \mathrm{~N}=58)$ but were not correlated to ant size $(F=0.20, \mathrm{p}=0.658, \mathrm{~N}=58)$. Théoule, the most eastern region of Corsican supercolony, did not show significant differences with the two others (Table S4d; Fig. 1b).

Differences in Iridomyrmecin among Supercolonies. Finally, when we compared the supercolonies (with four categories: Main, Catalonian, Corsican and native range), we obtained that iridomyrmecin quantities varied among them $(L R T=12.70, \mathrm{p}=0.005, \mathrm{~N}=660)$ and were positively correlated to the ant size ( $L R T=$ $17.21, p<0.001, N=660$ ). When comparing native and invaded ranges, the a priori contrast did not show differences in iridomyrmecin quantities ( $p=0.983$, Table S4e). Pairwise comparisons showed significant differences only in the invasive range between the Corsican and the Main supercolonies $(p=0.006, N=$ 479) with the Corsican having the highest iridomyrmecin value and the Main supercolony having the lowest value; but there were no differences between the Catalan and the Main supercolonies or between the Catalan and the Corsican supercolonies (Table S4e; Fig. 1b).

\section{Discussion}

We assessed whether quantities of iridomyrmecin, the main defensive compound of the invasive Argentine ant, could both vary between native and invaded areas, and contribute to the differential invasion success of three invasive supercolonies, with the assumption that the venom contributes to the success of the invasion. Contrary to what was expected, we observed no difference in iridomyrmecin amounts between the native and the invasive ranges. Moreover, even if the amount of iridomyrmecin varied within and among some invasive supercolonies, these differences did not seem to be related to the success of invasion. Within the introduced range, the Corsican supercolony had the highest quantities of iridomyrmecin while the most successful supercolony, i.e. the Main supercolony, had the lowest quantities. The Catalonian supercolony and the native colonies in Buenos Aires had intermediate values. Thus, our results suggest that the competitive ability of the invader does not only rely on the main defensive compound, iridomyrmecin.

Chemical defensive compounds could be used by invasive ants to facilitate predation. Although both fire ants (S. invicta and W. auropunctata) have a generalized diet, a typical characteristic of invasive ants (Holway et al. 2002), they can also obtain protein-rich sources from invertebrates and potentially small vertebrates (Romanski 2001; Holway et al. 2002; Ness and Bronstein 2004). The presence of a venomous painful sting that induces anaphylaxis increases their ability to consume this prey (Holway et al. 2002). Together with the recent discovery that the Argentine ant uses iridomyrmecin to kill young amphibians (Alvarez-Blanco et al. 2021), all these toxic chemicals could appear to influence invasiveness of these species, by increased prey predation. However, analysis of diets using stable isotopes have shown opposite results, indicating that in the invasive range invaders usually have a more herbivore diet due to increased mutualistic interactions with hemipterans (e.g., Wilder et al. (2011) for S. invicta, or Wittman et al. (2018) for A. gracilipes). This common trend stands also for the Argentine ant, although some variability in its trophic position and diet breath has been shown in invasive supercolonies (Tillberg et al. 2007; Seko et al. 2021). Thus, it is more likely that there is higher plasticity in response to local conditions 
(as it seems to occur in other invasive ant species; e.g., Balzani et al. (2021), and that toxic chemicals do not specifically increase predation in the invasive range.

Invasive ants, including the Argentine ant, are also known to use chemical attack in interspecific and intraspecific competition (e.g. Buczkowski and Bennett 2008; Blight et al. 2010; Abril and Gómez 2011). However, little is known about the role of specific chemical compounds in the dominance of the Argentine ant against competitors. Welzel et al. (2018) reported that Argentine ants deploy glandular secretions, mainly volatile iridoids (i.e. dolichodial and iridomyrmecin), during aggressive interspecific interactions by applying them directly on their competitor's surface. The use of iridoids directly applied on competing ants is also common on other ant species, both Dolichoderinae ants, such as Tapinoma melanocephalum and T. erraticum, and non-Dolichoderinae ants such as Pheidole biconstricta (Kugler 1979; Tomalski et al. 1987; Davidson et al. 2005).

We expected a higher quantity of iridomyrmecin in invasive supercolonies than in native supercolonies, if the hypothesis that iridomyrmecin influences invasiveness is true; alternatively, we could expect higher quantity in the native range due to forced competition - of that native small supercolonies - with native species, which includes very aggressive ant species such as $S$. invicta. Instead of that, our results showed no differences in amounts of iridomyrmecin between native and invasive areas. This result suggests that the success of the invasion is unrelated to the defensive compounds. The high variability among supercolonies irrespective of their geographic origin is in agreement with other works. For example, high levels of phenotypic plasticity have been suggested to account for behavioral differences between supercolonies independently of their origin (native or invasive supercolonies, Blight et al. (2017)). Moreover, even if the venom appears to provide an advantage in interference competition during laboratory confrontations (Bertelsmeier et al. 2015a), or locally to eliminate native species, it does not appear to provide advantages in invasive ant global spread. At this scale, climatic suitability probably explains differences in the global distribution of invasive ants better than competitive ability. This is illustrated by the wider success of the Argentine ant compared to $S$. invicta and W. auropunctata (Janicki et al. 2016; Angulo et al. 2021), two invasive ants notorious for the high toxicity of their venom.

Venoms also imply a high metabolic expenditure (Wigger et al. 2002; Morgenstern and King 2013). If their quantities could be modulated in response to their need, it could be that venoms are not as important in competitive interactions in the invasive range than in the native range. Our results seem to partially agree with this hypothesis, because by reducing the iridomyrmecin quantities in the Main supercolony of the invasive range, the Argentine ant could have invested these freed resources in other fitness traits increasing its competitive ability and extending its global invasive distribution. The lowest iridomyrmecin amounts of the Main supercolony would thus be in line with the enemy release hypothesis and the evolution of increased competitive ability hypothesis (Catford et al. 2009; Ricciardi et al. 2013). The native range of the Argentine ant is also the native range of some of the most widely distributed and destructive invasive species (S. invicta, S. richteri, W. auropunctata) (Lowe et al. 2000; Josens et al. 2017). The coexistence among them is very likely the cause that these species have life history traits that promote invasiveness, such as high levels of aggressiveness and high interference ability that may allow 
them to defend and monopolize resources (Bertelsmeier et al. 2015b). Some of the dominance traits could, however, be relaxed in invaded areas, if there would be less needed than in their native range, with respect to other traits improving invasiveness.

Welzel et al. (2018) also showed that these secretions used in competitive interactions against other ant species caused not only irritation but also acted as an alarm to attract conspecific nestmates, carrying out an effective and coordinated group defense. Therefore, it is possible that $L$. humile would be taking advantage of this alarm function of iridoids for investing in a numerical increase at a population level instead of increasing iridomyrmecin quantities at individual level in order to offset the low toxicity and the temporary effect of iridoids (Cavill and Clark 1971; Attygalle and Morgan 1984; Welzel et al. 2018). In other words, it could be that there is strength in numbers in the invasive range, i.e. a higher number of conspecifics with low iridomyrmecin quantities defending together that would be more successful than fewer individuals with high iridomyrmecin quantities. This would mainly occur in invasion fronts where invasive Argentine ants are in contact with native species. Thus, iridomyrmecin quantities at invasion fronts should be explored to determine factors affecting iridomyrmecin variation at the local context.

Among invasive supercolonies, there was a high variability in the amounts of iridomyrmecin. The Main supercolony showed the lowest iridomyrmecin amounts in average, while the Corsican showed the highest amounts. Differences were significant between the Main and the Corsican supercolonies, but not between the Main and the Catalonian supercolony, despite it is known that the Main supercolony has stronger competitive ability than the Catalonian supercolony (Abril and Gómez 2011; Blight et al. 2017). Again, this seems to indicate that competitive abilities of a supercolony does not rely exclusively on iridomyrmecin.

One of the limitations of our analysis could be due to the measurement of only one compound. Although iridomyrmecin is the major component of defensive secretion of L. humile (Cavill and Houghton 1974), pygidial glands contain a battery of defensive compounds that act together. For example, dolichodial is another volatile iridoid in the pygidial gland secretions that is also used during aggressive interactions (Cavill et al. 1976; Welzel et al. 2018); other compounds can help iridomyrmecin to reach and stay in the target, such as iridodials (Attygalle and Morgan 1984); and it is also probable that other non-volatile and/or more polar compounds take part in defensive secretions (Welzel et al. 2018).

Growing concerns about the effects of alien species in recipient environments have promoted the publication of reviews that have tackled ecological hypothesis (Ricciardi et al. 2013; Jeschke et al. 2014), magnitude of impacts (Blackburn et al. 2014; Hawkins et al. 2015) as well as their geographic and taxonomic biases (Pyšek et al. 2008; Bellard and Jeschke 2016) in an attempt to integrate available information in useful conceptual frameworks for scientists, managers and policy makers. It has also been proposed to give top priority to those alien species with potentially high environmental impacts in order to distribute management resources efficiently (Blackburn et al. 2014; Kumschick et al. 2015; Booy et al. 2020). Considering the strong environmental impacts caused by the Argentine ant in invaded ecosystems and its worldwide distribution, the Argentine ant is likely one of the most urgent cases on 
which to focus research and management efforts. Our study opens the way of exploring the contribution of defensive compounds in the competitive ability and spread of this global invader.

\section{Declarations}

\section{Acknowledgements}

Ana Carvajal, Charlotte Hemingway, Sara Castro-Cobo, Miguel Lozano, Dailos Hernández-Brito, Sebastián Palacios, Roxana Josens, Nuria Morrow, Maria del Carmen Ramírez, Francisco Miranda and Isabel Afán. ICTS-RBD-CSIC provided logistic support during field work. We thank laboratory facilities at EBD (LEF, LEA, LPM, and LAST).

\section{Declarations}

\section{Funding}

Funds came from the Spanish MINECO and FEDER (CGL2013-43660-P, CGL2015-65807-P). Spanish MINECO also funded E.A. (RyC postdoctoral fellowship), P.A-B. (predoctoral fellowship [BES-2013064713]) and I.S. (JAE-Intro fellowship [JAEINT17-EX-0526])

\section{Conflicts of interest}

The authors have no conflicts of interest to declare that are relevant to the content of this article.

\section{Availability of data and material}

Data used for these analyses can be found in the supplementary material.

\section{Code availability}

Code used for these analyses is available in the supplementary material.

\section{Authors' contributions}

E.A. and P.A-B. came up with and designed the study. E.A, X.C., S.A., and O.B. carried out the field sampling and P.A-B. carried out the disturbance experiment. I.S., R.B. and P.A-B. performed the chemical 
analyses and the statistical analyses; E.A., I.S and P.A-B. analyzed the data and wrote the paper and all authors reviewed the text.

\section{Ethics approval}

Not applicable.

\section{Consent to participate}

Not applicable.

\section{Consent for publication}

All authors agreed to the submission of the final manuscript.

\section{References}

Abril S, Gómez C (2011) Aggressive behaviour of the two European Argentineant supercolonies (Hymenoptera: Formicidae) towards displaced native ant species of the north eastern Iberian Peninsula. Mymecological News 14:99-106

Alvarez-Blanco P, Broggi J, Cerdá X, et al (2020) Breeding consequences for a songbird nesting in Argentine ant' invaded land. Biol Invasions 2020229 22:2883-2898. https://doi.org/10.1007/S10530020-02297-3

Alvarez-Blanco P, Cerdá X, Hefetz A, et al (2021) Effects of the Argentine ant venom on terrestrial amphibians. Conserv Biol 35:216-226. https://doi.org/10.1111/cobi.13604

Angulo E, Hoffmann BD, Ballesteros-Mejia L, et al (2021) Economic costs of invasive alien ants worldwide. https://doi.org/10.21203/rs.3.rs-346306/v1

Aniszewski T (2015) Applied potential and current applications of alkaloids. In: Alkaloids: chemistry, biology, ecology and appplications, Second edi. Elsevier B.V., Helsinki, Finland, pp 346-420

Attygalle AB, Morgan ED (1984) Chemicals from the glands of ants. Chem Soc Rev 13:245. https://doi.org/10.1039/cs9841300245

Balzani P, Vizzini S, Frizzi F, et al (2021) Plasticity in the trophic niche of an invasive ant explains establishment success and long-term coexistence. Oikos 130:691-696. 
Bates D, Mächler M, Bolker BM, Walker SC (2015) Fitting linear mixed-effects models using Ime4. J Stat Softw 67:1-48. https://doi.org/10.18637/jss.v067.i01

Bellard C, Jeschke JM (2016) A spatial mismatch between invader impacts and research publications. Conserv Biol 30:230-232. https://doi.org/10.1111/cobi.12611

Bertelsmeier C, Avril A, Blight O, et al (2015a) Different behavioural strategies among seven highly invasive ant species. Biol Invasions 17:2491-2503. https://doi.org/10.1007/s10530-015-0892-5

Bertelsmeier C, Avril A, Blight O, et al (2015b) Discovery-dominance trade-off among widespread invasive ant species. Ecol Evol 5:2673-83. https://doi.org/10.1002/ece3.1542

Bertelsmeier C, Keller L (2018) Bridgehead Effects and Role of Adaptive Evolution in Invasive Populations. Trends Ecol Evol 33:527-534. https://doi.org/10.1016/j.tree.2018.04.014

Billen J (1986) Morphology and Ultrastructure of the Abdominal Glands in the Dolichoderine Ants (Hymenoptera, Formicidae). Insectes Soc 33:278-295

Billen J, Morgan D (1998) Pheromone Communication in Social in Social Insects: Sources and Secretions. In: Meer RK Vander, Breed MD, Espelie KE, Winston ML (eds) Pheromone Communication in Social Insects: Ants, Wasps, Bees and Termites. pp 3-33

Blackburn TM, Essl F, Evans T, et al (2014) A Unified Classification of Alien Species Based on the Magnitude of their Environmental Impacts. PLoS Biol 12:. https://doi.org/10.1371/journal.pbio.1001850

Blancafort X, Gómez C (2005) Consequences of the Argentine ant, Linepithema humile (Mayr), invasion on pollination of Euphorbia characias (L.) (Euphorbiaceae). Acta Oecologica 28:49-55. https://doi.org/10.1016/j.actao.2005.02.004

Blight O, Berville L, Vogel V, et al (2012) Variation in the level of aggression, chemical and genetic distance among three supercolonies of the Argentine ant in Europe. Mol Ecol 21:4106-4121. https://doi.org/10.1111/j.1365-294X.2012.05668.x

Blight O, Josens R, Bertelsmeier C, et al (2017) Differences in behavioural traits among native and introduced colonies of an invasive ant. Biol Invasions. https://doi.org/10.1007/s10530-016-1353-5

Blight O, Renucci M, Tirard A, et al (2010) A new colony structure of the invasive Argentine ant (Linepithema humile) in Southern Europe. Biol Invasions 12:1491-1497.

https://doi.org/10.1007/s10530-009-9561-x

Blossey B, Notzold R (1995) Evolution of Increased Competitive Ability in Invasive Nonindigenous Plants: A Hypothesis. J Ecol 83:887-889. https://doi.org/10.2307/2261425 
Bolger DT, Suarez A V, Crooks KR, et al (2000) Arthropods in Urban Habitat Fragments in Southern California: Area, Age and Edge effects. Ecol Appl 10:1230-1248

Booy O, Robertson PA, Moore N, et al (2020) Using structured eradication feasibility assessment to prioritize the management of new and emerging invasive alien species in Europe. Glob Chang Biol 26:6235-6250. https://doi.org/10.1111/gcb.15280

Brandt M, Van Wilgenburg E, Tsutsui ND (2009) Global-scale analyses of chemical ecology and population genetics in the invasive Argentine ant. Mol Ecol 18:997-1005. https://doi.org/10.1111/j.1365294X.2008.04056.x

Buczkowski G, Bennett GW (2008) Detrimental Effects of Highly Efficient Interference Competition: Invasive Argentine Ants Outcompete Native Ants at Toxic Baits. 37:741-747. https://doi.org/10.1603/0046-225X(2008)37[741:DEOHEI]2.0.CO;2

Castro-Cobo S, Blight O, Espadaler X, Angulo E (2021) Long-term spread of Argentine ant (Hymenoptera: Formicidae) European supercolonies on three Mediterranean islands | Myrmecological News. Mymecological News 31:185-200. https://doi.org/10.25849/myrmecol.news_031:185

Catford JA, Jansson R, Nilsson C (2009) Reducing redundancy in invasion ecology by integrating hypotheses into a single theoretical framework. Divers Distrib 15:22-40. https://doi.org/10.1017/CB09781107415324.004

Cavill GWK (1969) Insect terpenoids and nepatalactone. In: Taylor WI, Battersby AR, Dekker M (eds) Cyclopentanoid Terpene Derivatives. New York, NY, pp 203-38

Cavill GWK, Clark D V. (1971) Ant secretions and cantharidin. In: Jacobson M, Crosby DG (eds) Naturally Occurring Insecticides. Marcel Dekker, pp 271-305

Cavill GWK, Houghton E (1974) Volatile Constituents of the Argentine Ant, Iridomyrmex humilis. 20:20492059

Cavill GWK, Houghton E, McDonald FJ, Williams PJ (1976) Isolation and characterization of dolichodial and related compounds from the argentine ant, Iridomyrmex humilis. Insect Biochem. https://doi.org/10.1016/0020-1790(76)90072-X

Choe D-H, Millar JG, Rust MK, Hildebrand JG (2009) Chemical signals associated with life inhibit necrophoresis in Argentine ants. PNAS 106:8251-8255

Choe DH, Villafuerte DB, Tsutsui ND (2012) Trail Pheromone of the Argentine Ant, Linepithema humile (Mayr) (Hymenoptera: Formicidae). PLoS One 7:e45016. https://doi.org/10.1371/journal.pone.0045016

Christian CE (2001) Consequences of a biological invasion reveal the importance of mutualism for plant communities. Nature 413:635-639. https://doi.org/10.1038/35098093 
D’Ettorre P, Lenoir A (2010) Nestmate Recognition. In: Lach L, Parr CL, Abbott KL (eds) Ant Ecology. Oxford Univ.Press, Oxford, pp 194-383

Davidson DW, Clark DA, Jones TH (2005) Gastral exocrine products of a myrmicine ant strongly overlap pygidial gland products of Dolichoderinae. Insectes Soc 52:305-308. https://doi.org/10.1007/s00040005-0810-4

Elton CS (1958) The Ecology of Invasions by Animals and Plants. Springer US, Boston, MA

Fox J, Weisberg S (2011) An \{R\} Companion to Applied Regression, Second. Sage, Thousand Oaks CA

Franzyk H (2000) Classification of Iridoids. In: Synthetic Aspects of Iridoid Chemistry. Springer, Vienna, pp $2-7$

Giraud T, Pedersen JS, Keller L (2002) Evolution of supercolonies: The Argentine ants of southern Europe. Proc Natl Acad Sci. https://doi.org/10.1073/pnas.092694199

GISD (2021) Global Invasive Species Database. http://www.iucngisd.org/gisd/100_worst.php on 07-042021. Accessed 7 Apr 2021

Hawkins CL, Bacher S, Essl F, et al (2015) Framework and guidelines for implementing the proposed IUCN Environmental Impact Classification for Alien Taxa (EICAT). Divers Distrib 21:1360-1363. https://doi.org/10.1111/ddi.12379

Helanterä H, Strassmann JE, Carrillo J, Queller DC (2009) Unicolonial ants: where do they come from, what are they and where are they going? Trends Ecol. Evol.

Holway DA, Lach L, Suarez A V., et al (2002) The Causes and Consequences of Ant Invasions. Annu Rev Ecol Syst 33:181-233. https://doi.org/10.1146/annurev.ecolsys.33.010802.150444

Holway DA, Suarez A V. (2004) Colony-structure variation and interspecific competitive ability in the invasive Argentine ant. Oecologia. https://doi.org/10.1007/s00442-003-1414-1

Hothorn T, Bretz F, Westfall P (2008) Simultaneous Inference in General Parametric Models. Biometrical J 50:346-363. https://doi.org/10.1002/BIMJ.200810425

Janicki J, Narula N, Ziegler M, et al (2016) Visualizing and interacting with large-volume biodiversity data using client-server web-mapping applications: The design and implementation of antmaps.org. Ecol Inform 32:185-193

Jeschke JM, Bacher S, Blackburn TM, et al (2014) Defining the impact of non-native species. Conserv Biol 28:1188-1194. https://doi.org/10.1111/cobi.12299

Josens R, Sola F, Lois-Milevicich J, Mackay W (2017) Urban ants of the city of Buenos Aires, Argentina: species survey and practical control. Int J Pest Manag 63:213-223. 
Kugler C (1979) Alarm and defense: a function for the pygidial gland of the Myrmicine ant, Pheidole biconstricta. Ann Entomol Soc Amer 72:532-536

Kumschick S, Bacher S, Evans T, et al (2015) Comparing impacts of alien plants and animals in Europe using a standard scoring system. J Appl Ecol 52:552-561. https://doi.org/10.1111/1365-2664.12427

Leclercq S, Braekman JC, Daloze D, Pasteels JM (2000) The Defensive chemistry of ants. In: Herz W, Falk H, Kirby GW, Moore RE (eds) Fortschritte der Chemie organischer Naturstoffe / Progress in the Chemistry of Organic Natural Products. Fortschritte der Chemie organischer Naturstoffe / Progress in the Chemistry of Organic Natural Products, vol 79. Springer, Vienna, pp 115-229

Lenth R V. (2016) Least-Squares Means: The R package Ismeans. J Stat Softw 69:1-33. https://doi.org/10.18637/jss.v069.i01

Lowe S, Browne M, Boudjelas S, De Poorter M (2000) 100 of the World's Worst Invasive Alien Species A selection from the Global Invasive Species Database. Invasive Species Spec Gr a Spec Gr Species Surviv Comm World Conserv Union 12

McKinney, Lockwood (1999) Biotic homogenization: a few winners replacing many losers in the next mass extinction. Trends Ecol Evol 14:450-453

McKinney ML, Lockwood JL (2001) Biotic Homogenization: A Sequential and Selective Process. In: Biotic Homogenization. Springer US, Boston, MA, pp 1-17

Millennium Ecosystem Assessment, 2005. Ecosystems and Human Well-being: Synthesis.

Island Press, Washington, DC.

Morgenstern D, King GF (2013) The venom optimization hypothesis revisited. Toxicon 63:120-128. https://doi.org/10.1016/j.toxicon.2012.11.022

Ness JH, Bronstein JL (2004) The Effects of Invasive Ants on Prospective Ant Mutualists. Biol Invasions 6:445-461. https://doi.org/10.1023/B:BINV.0000041556.88920.dd

Pavan M (1949) Ricerche sugli antibiotica di origine animale. Atti della Soc Ital di Sci Nat e del Mus Civ di Stor Nat di Milano (Testo Stamp 88:136-141

Pavan M (1952a) "Iridomyrmecin” as insecticide. Trans Ninth Int Congre Ent 1:321-325

Pavan M (1952b) Primo contributo sperimentale allo studio farmacologico della iridomirmecina. Arch int pharmacodyn LXXXIX:223-228 
Pedersen JS, Krieger MJB, Vogel V, et al (2006) Native supercolonies of unrelated individuals in the invasive argentine ant. Evolution (N Y) 60:782-791. https://doi.org/10.1111/j.0014-3820.2006.tb01156.x

Pyšek P, Richardson DM, Pergl J, et al (2008) Geographical and taxonomic biases in invasion ecology. Trends Ecol Evol. https://doi.org/10.1016/j.tree.2008.02.002

R Core Team (2016) R: A language and environment for statistical computing.

Ricciardi A, Hoopes M, Marchetti MP, Lockwood JL (2013) Progress toward understanding the ecological impacts of nonnative species. Ecol Monogr 83:263-282. https://doi.org/10.1890/13-0183.1

Romanski A (2001) Introduced Species Summary Project: Little Fire Ant (Wasmannia auropunctata). http://www.columbia.edu/itc/cerc/danoffburg/invasion_bio/inv_spp_summ/Wasmannia_auropunctata.htm\#Establishment. Accessed 7 Apr 2018 Seko Y, Hashimoto K, Koba K, et al (2021) Intraspecific differences in the invasion success of the Argentine ant Linepithema humile Mayr are associated with diet breadth. Sci Reports 2021 111 11:1-10. https://doi.org/10.1038/s41598-021-82464-1

Senar JC (1999) Medición de la Repetibilidad y el Error de Medida. Etologuía 17:53-64

Sih A, Bolnick DI, Luttbeg B, et al (2010) Predator-prey naïveté, antipredator behavior, and the ecology of predator invasions. Oikos 119:610-621. https://doi.org/10.1111/j.1600-0706.2009.18039.x

Suarez A V., Richmond JQ, Case TJ (2000) Prey selection in horned lizards following the invasion of Argentine ants in southern California. Ecol. Appl. 10:711-725

Suarez A V., Tsutsui ND (2008) The evolutionary consequences of biological invasions. Mol Ecol 17:351360. https://doi.org/10.1111/j.1365-294X.2007.03456.x

Suarez A V, Holway DA, Case TJ, Schoener TW (2001) Patterns of spread in biological invasions dominated by long-distance jump dispersal: Insights from Argentine ants. Proc Natl Acad Sci 98:10951100

Suarez A V, Tsutsui ND, Holway DA, Case TJ (1999) Behavioral and genetic differentiation between native and introduced populations of the Argentine ant. Biol Invasions 1:43-53

Sunamura E, Espadaler X, Sakamoto H, et al (2009) Intercontinental union of Argentine ants: Behavioral relationships among introduced populations in Europe, North America, and Asia. Insectes Soc 56:143147. https://doi.org/10.1007/s00040-009-0001-9

Thomas ML, Tsutsui ND, Holway DA (2005) Intraspecific competition influences the symmetry and intensity of aggression in the Argentine ant. Behav Ecol 16:472-481.

https://doi.org/10.1093/BEHECO/ARI014

Page $17 / 20$ 
Tillberg C V., Holway DA, LeBrun EG, Suarez A V. (2007) Trophic ecology of invasive Argentine ants in their native and introduced ranges. Proc Natl Acad Sci 104:20856-20861.

https://doi.org/10.1073/PNAS.0706903105

Tomalski MD, Blum MS, Jones TH, et al (1987) Chemistry and functions of exocrine secretions of the antsTapinoma melanocephalum and T. erraticum. J Chem Ecol 13:253-263.

https://doi.org/10.1007/BF01025886

Tsutsui ND, Case TJ (2001) Population Genetics and Colony Structure of the Argentine Ant (Linepithema humile) in its Native and Introduced Ranges. Evolution (N Y) 55:976-985. https://doi.org/10.1111/j.00143820.2001.tb00614.x

Tsutsui ND, Suarez A V., Holway DA, Case TJ (2000) Reduced genetic variation and the success of an invasive species. Proc Natl Acad Sci. https://doi.org/10.1073/pnas.100110397

Vogel V, Pedersen JS, D'Ettorre P, et al (2009) Dynamics and genetic structure of argentine ant supercolonies in their native range. Evolution (N Y) 63:1627-1639. https://doi.org/10.1111/j.15585646.2009.00628.x

Vogel V, Pedersen JS, Giraud T, et al (2010) The worldwide expansion of the Argentine ant. Divers Distrib 16:170-186. https://doi.org/10.1111/j.1472-4642.2009.00630.x

Welzel KF, Lee SH, Dossey AT, et al (2018) Verification of Argentine ant defensive compounds and their behavioral effects on heterospecific competitors and conspecific nestmates. Sci Rep 8:1-15. https://doi.org/10.1038/s41598-018-19435-6

Wetterer JK, Wild AL, Suarez A V., et al (2009) Worldwide spread of the Argentine ant, Linepithema humile (Hymenoptera: Formicidae). Myrmecological News 12:187-194

Wigger E, Kuhn-Nentwig L, Nentwig W (2002) The venom optimisation hypothesis: a spider injects large venom quantities only into difficult prey types. Toxicon 40:749-52

Wilder SM, Holway DA, Suarez A V., et al (2011) Intercontinental differences in resource use reveal the importance of mutualisms in fire ant invasions. Proc Natl Acad Sci 108:20639-20644.

https://doi.org/10.1073/PNAS.1115263108

Wittman SE, O'Dowd DJ, Green PT (2018) Carbohydrate supply drives colony size, aggression, and impacts of an invasive ant. Ecosphere 9:e02403. https://doi.org/10.1002/ecs2.2403

\section{Figures}


(a)

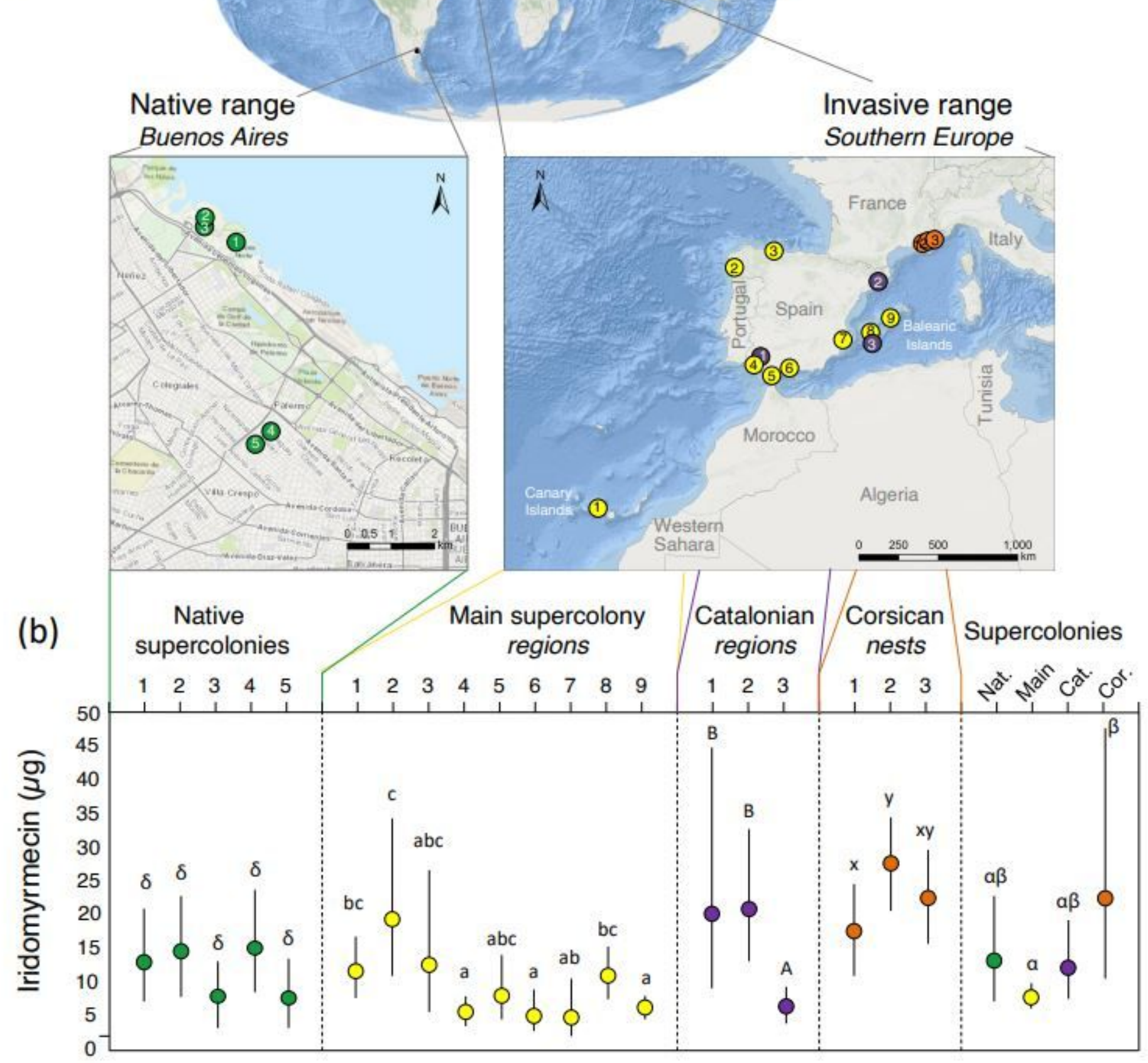

\section{Figure 1}

(a) Map of study area and sampling points. (b) Average (Ismean $\pm \mathrm{CL}$ ) iridomyrmecin quantities among the supercolonies of the native range (green), among different regions of the Main supercolony in the invasive range (yellow), among different regions of the Catalonian supercolony in the invasive range (purple), among different nests of the Corsican supercolony (orange) and among supercolonies (green, 
yellow, purple and orange for the Natives, Main, Catalonian and Corsican, respectively). For more information, see Table S1.

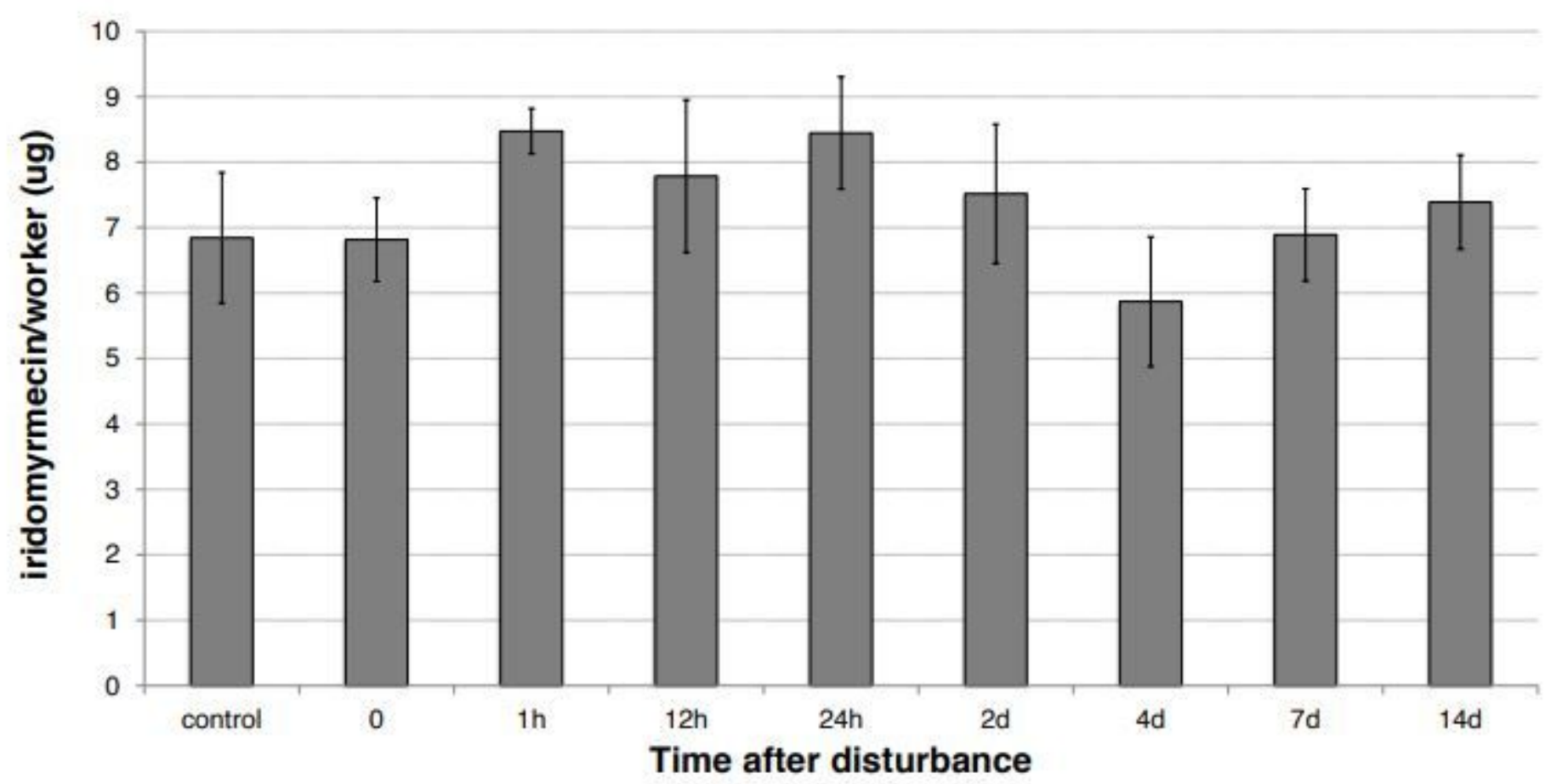

Figure 2

Changes in iridomyrmecin quantities (mean $\pm \mathrm{SE}$ ) following disturbance. Time after disturbance corresponds to: 0 , just disturbed; 1,12 , and $24 \mathrm{~h}$ after disturbance; 2, 4, 7 and 14 days after disturbance. The control corresponds to workers sampled from trails without disturbance, prior to collection of the colony fragment for the experiment.

\section{Supplementary Files}

This is a list of supplementary files associated with this preprint. Click to download.

- SupMatCode1LhAnalyses.r

- SupMatCode2disturbance.r

- SupMatCode3repeatabilitypop.r

- SupMatData.xIsx

- SupMatTables.pdf 